\title{
SUSANNE BISGAARD
}

\section{AT HØRE, AT HØRE EFTER, AT HØRE TIL}

\section{Strategier i forbindelse med høretab og høreapparater}

Hvad bruger vi hørelsen til, hvad sker der, når lyden aftager, og hvordan bruges høreapparater til at bevare kontakten til omverdenen? Så længe høreevnen er intakt, bevares muligheden for at deltage $\mathrm{i}$ forhandlingen og produktionen af sociale og kulturelle værdier i de sammenhænge, som den enkelte tilskriver betydning. Der kan være store individuelle forskelle på, hvordan høretabet håndteres. Nogle ønsker fortsat at kunne deltage $\mathrm{i}$ alle livets sammenhænge, mens andre blot ønsker at bevare kontakten til helt specifikke dele af livsverdenen.

Hørelsen er anderledes end synet på den måde, at lyden kommer til os, ligegyldigt hvordan vi vender os i rummet, hvorimod vi kan vende ryggen til det, vi ikke ønsker at se. Vi hører lyd, der kommer alle vegne fra: bagfra, rundt om hjørner og inde fra naboen. Alligevel er det sådan, at vi hører, og vi hører ikke. Nogle af de lyde, vi hører, tilskriver vi en mening, de sætter refleksioner i gang, og måske handler de om rene erindringsbilleder, som når en melodi fremkalder minder om forgange begivenheder. Andre gange kræver de også indgriben, som når vi hører, at grøden koger over, eller nogen tager i dørhåndtaget på hoveddøren. Så er det de stumme tings lyd (Ihde 1976), som får os til at reagere - de giver normalt ikke lyd fra sig, men tingene bringes i bevægelse af menneskelig aktivitet. Atter andre lyde lukker vi ude, fordi vi ved, de bare er der - såsom den bærbares ventilator og varmeapparatets klukken.

Lyd i form af tale giver os mulighed for at bevare den position, som vi til stadighed genforhandler i de forskellige roller, vi indtager, når vi er sammen med de mennesker, der har betydning i vores liv.

\section{Perspektiver på lyd}

Hvis lyden ikke giver mening, kan vi definere den som irrelevant. Psykologer og fysiologer vil sige, at det limbiske system hjælper os med at frasortere de sanseindtryk, vi ikke har 
brug for her og nu. Sanseindtryk kan altså under nogle omstændigheder styres. Georg Simmel (1908) definerer sanserne som en bro til omverdenen, og på det grundlag kunne de være en prækulturel størrelse. Men de er nok snarere krypterede instrumenter, der oversætter kropslige erfaringer til kulturelt genkendelige former. På den måde formidler sanserne indtryk i en vekselvirkning mellem socialt foreskrevne normer og individuelle forestillinger og behov. Også disse er dybest set variationer over kulturelle temaer, idet det individuelle falder inden for mønstre, som bærer en genkendelig kulturel prægning (Herzfeld 2001:244).

Alle mennesker har altså i et vist omfang en selektiv hørelse. Men hvis man har et høretab, der gør det vanskeligt at høre i dårlig akustik, i baggrundsstøj, når man ikke har kendskab til dét, der bliver talt om, eller der bliver talt i en dialekt eller på et fremmed sprog, som man ikke kender som sit eget, kræver det stor koncentration at lytte. At lytte under sådanne omstændigheder forudsætter ofte en stærk identifikation med den pågældende sociale kontekst samtidig med et behov for at bevare eller styrke en position inden for denne. Dette er en mental anstrengelse, som tit har et fysisk udtryk gennem kropslig anspændthed. ${ }^{1}$

\section{Perspektiver på høretab}

Denne artikel omhandler den fremadskridende hørenedsættelse hos voksne, der kan afhjælpes med et høreapparat, og er baseret på min undersøgelse af en række personers holdninger til (eget) høretab samt deres strategier med hensyn til at bruge (eller ikke at bruge) høreapparater. ${ }^{2}$ Den hørehæmmede kan gennem høretabet blive ekskluderet fra en række sammenhænge i livsverdenen, men har mulighed for i et vist omfang at rette op på dette med et høreapparat. Nogle hørehæmmede anvender høreapparatet i alle deres vågne timer, andre bruger det kun $\mathrm{i}$ bestemte sammenhænge. Forskellen skyldes dels fysiologiske og teknologiske forhold, idet der ikke er to høretab, der opleves ens, ligesom teknologien i høreapparatet kan hjælpe brugeren til at høre bedre, men ikke genskaber naturlig hørelse. Dels er der forskel på det fokus, den enkelte har på de forskellige sociale sammenhænge, han/hun indgår i, og hvilke bestræbelser der gøres for at deltage. Det er imidlertid et fællestræk, at den hørehæmmede gennemgår en proces, hvor det fysisk betingede høretab indordnes i livsverdenen. I den proces bevæger den enkelte sig fra at være normalthørende til at være hørehæmmet, og de refleksioner, der kommer til udtryk, er genspejlinger af almindelige og differentierede samfundsmæssige holdninger til ønsket om deltagelse i samfundslivet, til funktionsnedsættelse og kropslig fremtoning.

Samtidig er processen individuel, fordi den forhandles ud fra personlig livssituation og livssyn i samspil med den disciplinering, som samfundet udsætter den hørehæmmede for. Hørehæmmede skal leve med, at de ved at blive høreapparatbrugere kommer til at tilhøre en gruppe, som de i vekslende omfang ikke har lyst til at tilhøre. Nogle anser blot 
høreapparater som et redskab, der hjælper mennesker til at høre bedre. Men som oftest tolkes brugen af høreapparater inden for et værdihierarki af fysiske og sociale forskelle (Stratton 1999:65). Nogle brugere giver således udtryk for skam- og skyldfølelser såvel over deres høretab som over at bruge høreapparat.

Et vigtigt tema i forbindelse med hørelse er den sociale kontrol, som rent sprogligt udøves for at få deltagere i en gruppe til at skabe mening med interaktionen på samme måde. Det medvirker til, at betegnelser for tilstanden ,,at høre dårligt" for nogle bliver et ømtåleligt spørgsmål, hvor de forsøger at undgå at give sig selv eller andre stemplet „fysisk defekt". Den fysiske defekt kan få samfundet til at sætte spørgsmålstegn ved evnen til at være kulturbærende. Imidlertid adskiller en hørenedsættelse sig fra de fleste andre funktionsnedsættelser, ved at det i højere grad er muligheden for at være kulturbærende, der rammes.

Den enkeltes livssyn, herunder mulige negative associationer forbundet med funktionsnedsættelse, og andres dårlige erfaringer med høreapparater kan gøre det vanskeligt for hørehæmmede at tage beslutning om at anskaffe apparaterne. Mit udgangspunkt er, at det først er i det øjeblik, at den enkeltes selvforståelse som indehaver af en bestemt social position må ændres, at der tages skridt til at blive høreapparatbruger. Samtidig ligger der på flere niveauer et konfliktpotentiale i en hørenedsættelse, idet der dels kan opstå strid på grund af misforståelser fra den hørehæmmedes side, dels er dét, den hørehæmmede ønsker at høre, ikke nødvendigvis det samme som det, de pårørende ønsker at kommunikere med ham eller hende om.

\section{At høre, at høre efter, at høre til}

Et ydre perspektiv på betydningen af at høre kommer til udtryk gennem den samfundsmæssige disciplinering, idet sproget genspejler en social kontrol. I vores daglige omgang med ,at høre" foretager vi en socialt konstrueret sammenblanding af tre forskellige fænomener og begreber, nemlig den rent fysiske/neurologiske perception ,at kunne høre“, ,,at høre efter" $\mathrm{i}$ betydningen at adlyde og ,,at høre til“" i betydningen at forstå, hvad det drejer sig om i en bestemt sammenhæng, og at blive anerkendt. De fysiske sansemuligheder, som vores krop giver os, bliver på denne måde udgangspunkt for vores væren i verden, fordi det er meningsskabende for vores eksistens, hvad vi hører, og hvordan vi agerer på det. Samtidig kan man ud fra de nedenstående eksempler aflæse, at et høretab ikke kun medfører et tab for den enkelte hørehæmmede. Hørelsen som sådan udgør en væsentlig del af sammenhængskraften i den måde, vi interagerer med andre mennesker på. Derfor medfører et høretab hos den enkelte ikke blot en risiko for eksklusion, men også at gruppen lider et tab i forbindelse med forhandling og produktion af sociale og kulturelle værdier.

Rent sprogligt afspejles ovennævnte sammenblanding af betydninger i ,at høre“ $\mathrm{i}$ stammen i de ord, der ofte anvendes i forbindelse med lyd/hørelse/forståelse/adlydelse. 
„Lydhør“ indeholder stammen af både lyd (budskabet, der afsendes) og hørelsen som den, der skal modtage et budskab. Derudover bruges det idiomatiske udtryk, at slå til lyd for" som et udtryk for, at lyden bliver brugt som forbindende element i forsøg på at skabe en fælles klangbund i en social sammenhæng. At noget „tilhører“én, kan tolkes som noget, der følger sin ejers bud. Samtidig dækker ,tilhøre“ over, at vi hører til, eller at vi ikke hører til, hvilket deler os op i dem, der taler med én tunge, og dem, der ikke deler de samme værdier, som vi gør - eller måske endnu værre: taler med to tunger. Samhørighed er noget, man har med dem, som tilskriver det, der sker omkring os, en fælles mening. At råbe „,hørt“ viser, at man er enig. „Uhørt“ udtrykker noget, der ikke er normalt og accep-tabelt, og som derfor indgår som element i et modsætningsforhold, som er meningsskaben-de, idet vi bruger det til at definere os som det „hørte“. Både dansk, engelsk og tysk har ordsprog med samme grundholdning til at høre: „Den, der ikke vil høre, må føle“, „He who will not hear advice, must suffer“, „,Wer nicht hören will, muss fühlen“. I ordet „lydig“ drejer det sig om at bøje sig for lyd, lydig har endvidere et betydningssammenfald med,,at høre efter", som både betyder at rette sig efter det, andre siger, og at koncentrere sig om det, andre siger. ”Så hør dog efter! “henvender sig ikke til det at kunne høre, men at ville høre. Den vrede og irritation, som forældre og andre opdragere udsætter børn for, når de skal opføre sig efter normen, eller når de udsætter sig selv for fare, kan være bevidste eller ubevidste forsøg på at få barnet til at skamme sig på grund af den afvigende adfærd. Skam på grund af afvigelse overføres til andre forhold, hvilket igen tvinger de hørehæmmede til at udfordre både egen og andres antagelse om, at de ikke kan forstå, fordi de ikke er opmærksomme nok. De skammer sig altså ikke kun over høretabet, de skal også håndtere andre menneskers irritation over, at de ikke hører ordentligt efter (Boisen 1989).

Budskabet synes at være, at hvis du ikke kan høre os, hører du ikke til hos os. Hvis du ikke skaber mening i din kommunikation på samme måde, som vi gør, så kan du ikke opretholde din position i vores gruppe. Nogle gange er det den enkelte, der selv gør en stor indsats for at vedblive med at være en del af de sociale netværk. Andre gange er det den sociale kontrol, der forlanger, at vi hører, og hvis man er hørehæmmet, forsøger de andre måske at få vedkommende ind på række igen ved hjælp af et høreapparat.

\section{Hørehæmmet?}

Når man hører dårligt, er man så et menneske med et høretab, er man hørehæmmet, hørehandicappet eller måske tunghør? For en udenforstående er det vel flere udtryk for den samme ting. Men så simpelt er det ikke for dem, der er berørt af problemet. For nylig holdt jeg et foredrag for en stor gruppe behandlere og brugere inden for høresundhedssektoren. Jeg brugte betegnelsen „hørehæmmede“. I den efterfølgende pause kom en høreapparatbruger hen til mig og sagde, at hun havde kunnet genfinde sig selv i mit foredrag, og at hun var tilfreds med, at jeg havde sagt „,ørehæmmet“, for det betegnede hendes situa- 
tion. Hvis man derimod brugte betegnelsen „menneske med et høretab“, følte hun, det var en byrde, hun slæbte rundt på, og at det derudover var en tung sproglig konstruktion, når man skrev om det. Efter pausen holdt en anden høreapparatbruger med et alvorligt høretab et oplæg. Med klar henvisning til mit indlæg gjorde hun opmærksom på, at hun var stærkt utilfreds med betegnelsen ,hørehæmmet“, der for hende havde nogle negative associationer, fordi det anfægtede hendes evner, og hun var i øvrigt ikke hæmmet. Hendes holdning genspejles i markedsføringen af høreapparater, der ikke bruger udtryk, som klassificerer det defekte menneske, fx hørehæmmet, hørehandicappet, tunghør. I stedet bruges udtryk som „menneske med et høretab“, som anses for at være mere skånsomt.

I min undersøgelse spurgte jeg deltagerne, hvordan de betegnede deres hørenedsættelse, dvs. om de klassificerede den som en sygdom, en aldersbetinget lidelse eller et handicap. Det store flertal sagde, at det havde noget at gøre med alder, men de tog afstand fra betegnelsen handicap, da det var en alvorligere tilstand, som kaldte på mere negative følelser. Jeg tolker denne afstandtagen fra at blive stemplet som handicappet som modstand mod at lade sig klassificere som defekt og derfor ikke længere fuldgyldig deltager i en gruppe. I kampen for tilværelsen stiller en fysisk defekt individet dårligere end det perfekte menneske, der ses som idealet. Samtidig er vi opdraget til, at hvis vi ikke hører efter, vil det gå os ilde, hvilket igen kan give anledning til skyldfølelse og skam over en pådraget funktionsnedsættelse.

Høretabet er en funktionsnedsættelse i lighed med andre, men den er kendetegnet ved, at muligheden for at være kulturbærende kan blive indskrænket. ${ }^{3}$ Antropologen Robert Murphy beskriver i monografien The Body Silent, hvordan samfundet gennem sin sociale orden sætter spørgsmålstegn ved handicappedes ret til at blive regnet som kulturbærende væsener (Murphy 1990:132). Det vil sige, at den handicappede ud over den funktionsnedsættelse, hun eller han må forsøge at overvinde i mødet med samfundet, klassificeres som et individ, der ikke er kulturbærende. For hørehæmmede består en stor del af handicappet netop i, at deres mulighed for at være kulturbærende svækkes, fordi det kan være vanskeligt at være aktiv deltager i en gruppe. Her definerer jeg kultur som den sociale praksis og de materielle og immaterielle værdier, som en social gruppe udvikler, forhandler, tilskriver ting og handlinger og videregiver til andre. I denne sammenhæng kan det ofte dreje sig om en nuancering af betydninger. Men hvis et begrænset sanseapparat betyder, at man har svært ved at opfatte, hvad der foregår omkring én, hvis man har vanskeligt ved at følge en samtale, kan også identifikationen med den sociale gruppe, som man opfatter sig som en del af, blive svækket. Samtidig kan den person, man er i dialog med, føle sig forvirret eller afvist, hvis den hørehæmmede foregiver at have forstået samtalen og på grund af misforståelse reagerer anderledes end forventet, hvilket igen kan føre til en marginalisering af den hørehæmmede. ${ }^{4}$

Det er ud fra ovenstående, at jeg hævder, at et hørehandicap adskiller sig fra andre handicap. For den hørehæmmede, der interagerer med andre, kræver det en stærk 
bevidsthed om handicappets særlige karakter at kunne blive ved med at deltage som kulturbærende inden for en social kontekst på samme måde som før, høretabet indtraf.

\section{At skilte med sin hørenedsættelse}

Hørenedsættelse betegnes ofte som et usynligt handicap - usynligt, fordi det ikke kan ses på de ramte, men også fordi mennesker med en hørenedsættelse har tendens til at forsvinde i den offentlige debat (Christensen 2006). Døve indtager tilsyneladende en mere prominent rolle i de flestes bevidsthed, idet mange begynder at tale om døve og cochlear implants, når jeg fortæller om min undersøgelse. Til sammenligning kan nævnes, at der er ca. 5.000 døve i Danmark, hvorimod der er mindst 500.000 (nogle undersøgelser taler om 800.000) mennesker i Danmark, der i en eller anden form har høreproblemer. Af disse har 250-300.000 høreapparater, og 200-250.000 yderligere kunne formentlig have udbytte af et høreapparat. Hvis høreapparater er den forkromede løsning på høreproblemer, hvorfor er der så ikke flere, der vælger dem?

Der synes at være en bemærkelsesværdig uoverensstemmelse mellem høreapparater som højt avanceret teknologi på den ene side og på den anden side deres image som et hjælpemiddel, mennesker sætter ind i øret, som hyler, og som har ørevoks på sig. Producenter og forhandlere reklamerer for deres høreapparater, men som Anders sagde, da jeg spurgte, om han ville have noget imod, at hans næste høreapparater blev mere synlige: „Der er ingen grund til at reklamere for sit høretab!“ Da jeg spurgte Henrik, hvorfor han havde været så længe om at beslutte sig til at få høreapparat, sagde han: „Der er så meget, man ikke kan, når man bliver ældre. Skal man så også gå rundt med et skilt, hvor der står: Jeg kan heller ikke høre!“

Der var altså flere af deltagerne i undersøgelsen, der mente, at de skiltede med en fysisk defekt, når de tog høreapparater på. Dét, at de ikke kunne høre så godt, var noget, de havde vænnet sig til, og det var heller ikke i alle situationer, at de ikke kunne høre. For eksempel er der måske ingen høreproblemer i et rum med fornuftig akustik og kun én lydkilde (se også Ryhl i dette nummer). Men hvis flere taler på en gang, og akustikken er dårlig, så vil mange hørehæmmede lade, som om de har hørt, hvad folk har sagt, hvilket kan give anledning til konflikter og misforståelser, som igen kan føre til skamfuldhed.

Jeg har følt mig meget udenfor, fordi jeg ikke har hørt alle de der småting ... sådan til fester, ... så har jeg været ude for, at der har siddet en pige og betroet mig nogle ting, sådan virkelig intimt eller hemmeligt ... og jeg kan jo ikke høre det, så sidder jeg bare der og smiler og nikker på de rigtige tidspunkter, og så tror de, jeg er fuldstændig idiot, for jeg kan ikke huske det bagefter, for jeg har jo ikke hørt det. (Ditte, 51).

Ved du, hvad jeg også har gjort - det skammer jeg mig lidt over - når man er i selskab ..., hvis der er en, der står og holder en tale, og alle de andre griner ... hvad griner de egentlig af? Så griner jeg med. Ellers tror de bare, jeg er dum. For det er jo flovt, at jeg ikke har fanget noget. Når nu netop taleren kigger på mig, hvad gør jeg så, skal jeg så sidde og sige, hvor alle 
de andre sidder og griner ... 'Jeg hørte ikke, hvad du sagde?' Så tager jeg et smil frem ... ellers har jeg ødelagt talen for ham. (Hanne, 74).

De to citerede kvinder havde begge vanskeligt ved at tage beslutningen om at blive høreapparatbrugere, men i sidste ende var det vigtigere for dem at være reflekterende, genkendte og anerkendte deltagere i forhandlingen og produktionen af sociale og kulturelle værdier i deres forskellige livssammenhænge. Imidlertid vil der som senere angivet være andre, der ikke bøjer sig for den sociale kontrol, der forsøger at få os til at være aktive deltagere $\mathrm{i}$ alle aspekter af tilværelsen.

Når det kan være svært at tage skridtet til at blive høreapparatbruger, skyldes det i nogle tilfælde forfængelighed, som kan forbindes med en kropslig fremmedgørelse.

For mig går det selvfølgelig op i, at det overhovedet ikke skal kunne ses ... altså, forfængelighed, ikke? Det er, fordi jeg synes, når man ikke kan høre, så er man gammel, og jeg føler mig jo ikke gammel, vel! (Britt, 57).

Britt havde nogle af de mindste høreapparater, der findes, men når hun gik ned ad hovedgaden i blæsevejr, var hun alligevel meget opmærksom på, at vinden ikke skulle blæse håret væk fra ørerne, så folk kunne få øje på hendes høreapparater. Det var lykkedes hende at skjule sit høretab for mennesker, der ikke kendte hende så godt, og det ramte hende hårdt, når andre kom med negative bemærkninger om høreapparater. Hun havde fortalt en veninde om en mand, som hun egentlig fandt ret attraktiv, men han var lidt kraftig og havde ikke så meget hår - men det, der for alvor fik den anden til at reagere negativt, var, at han havde høreapparater. „Det bliver da også værre og værre!“ var venindens kommentar. Sådanne bemærkninger holdt hendes egen oplevelse af høreapparater i live, nemlig at de symboliserede manglende attraktivitet.

\section{Den selektive hørelse}

Når man taler med pårørende til hørehæmmede, dukker der ofte en bemærkning op om, at de hører det, de vil høre. Hvad de pårørende glemmer er, at det for mange hørehæmmede er vigtigt at vide, hvad der bliver talt om, for at kunne følge med, fordi der for dem er „huller“ i lyden, som de bliver nødt til at udfylde med gæt. Jeg opfatter de pårørendes bemærkning som social kontrol, der går ud på at normalisere forholdet til den hørehæmmede. Det kan bunde i sorg over en reduceret social kontakt, men det sker oftere, at jeg støder på irritation og endog vrede over, at tingene skal gentages og misforståelser udredes, som det ofte er sket ifølge nedenstående citat.

Du siger et sted ... at det er dine omgivelser, der har haft mest glæde af høreapparatet, fordi du nu ikke taler så højt?

Anders: Det mener jeg stadigvæk.

Anders' kone: Alle de misforståelser, altså, når jeg sagde et eller andet, og så svarede han 
på noget andet. Så kunne han nogle gange sige: 'Hvorfor siger du det?' 'Det har jeg aldrig sagt!' Altså, fordi det er sådan, at man taler i øst og svarer i vest, ikke? Og det kan altså godt være sådan lidt irriterende, fordi det har jeg jo aldrig sagt, det der, men han har altså hørt det sådan, ikke? (Anders og hans kone).

Også på dette punkt kan der ligge et konfliktpotentiale i en hørenedsættelse, idet der er modstand mod at lade sig „konstruere“ socialt som hørehæmmet. Flere respondenter fraskrev sig ansvaret for ikke at kunne høre. Ofte er der dog et sammenfald med en erkendelse af, at de ikke hører så godt længere.

Men jeg plejer jo at sige, at min kone ikke vil tale tydeligt og vende ansigtet hen imod mig og lade være med at tale, når jeg er her, og hun er ude i badeværelset. Så må jeg investere i et par høreapparater, fordi det er ikke til at holde ud ... når Inge taler med sin søn her, så kan jeg overhovedet ikke høre, hvad de siger. Men han er altså også slem, han er endnu værre end sin mor, han siger blub blub blub blub. (Jens, 79).

Når Peter (57) ikke kan høre, hvad der bliver sagt, så ligger problemet i, at folk taler utydeligt. Især har han problemer med at høre kvinder. Han mener, at mennesker burde udelukkes fra at tale offentligt, hvis de ikke kan tale, så man kan forstå det.

Jeg tager referat til bestyrelsesmøder og direktionsmøder, og bordet er nogle gange langt ... ordstyreren sidder i den anden ende, og tit vender de så nakken til mig og nærmest mumler, ja, nogle gange bliver jeg tosset og synes, det er uforskammet. (Marianne, 59).

\section{Konstruktionen af et høretab}

Selv om det altså er sådan, at mange af respondenterne i undersøgelsen godt ved, at de har en hørenedsættelse, så gør de modstand mod at blive defineret som hørehæmmede ved at lægge ansvaret for det, de ikke hører, over på den talende. Der er imidlertid samtidig klare forskelle i de strategier, hørehæmmede vælger, for at håndtere deres hørenedsættelse. For eksempel sagde Halvor i et interview, hvor også hans meget talende kone deltog: „Høretab er guds gave til ældre ægtemænd!“ Udsagnet optrådte i mange forskellige varianter i undersøgelsen, og det kendetegner en tilbagetrækning fra en social kontekst, samtidig med at det er en klar afgrænsning i forhold til den interaktion, den anden ønsker at få respons på. Selv om det er præsenteret på en humoristisk måde, er det svært ikke at tolke det som en nedvurdering af det sociale liv inden for familien og manglende interesse for den anden.

Halvor havde dog trods alt glæde af sine høreapparater på forskellig vis. Han beskrev, at omkring ham genopstod en lydkulisse, han havde glemt eksisterede, og han kunne langt bedre deltage i sociale sammenhænge. Men han kunne også bruge sine høreapparater som ørepropper. Hvis hans kone så noget i fjernsynet, han ikke havde lyst til at se (høre), slukkede han for høreapparaterne, men beholdt dem på, da de hjalp ham til at holde den sidste rest af lyd ude, så han kunne koncentrere sig om sine elskede bøger. 
Karsten udtrykker igennem følgende citat en anden tilgang til at høre: „Høretab kan få dig til at holde op med at deltage. I så fald løber du væk fra livet!“ Angsten for at blive sat uden for det sociale liv er tydelig, og det udtrykker et ønske om at kunne kommunikere under alle livets forhold. Høreapparaterne havde altafgørende betydning for ham. Blandt andet satte de ham i stand til selv at tage stilling til, om det var væsentligt, hvad andre sagde. Han havde gjort den erfaring, at hvis han bad om at få gentaget, hvad folk sagde til ham, så sagde de tit: „Det var ikke vigtigt!“ Og det var det måske heller ikke, fx „,Det er dejligt vejr i dag!“‘. Det havde han allerede konstateret, men han ønskede at bevare muligheden for selv at tage stilling til, om noget var væsentligt eller ej. Når Karsten var ude at rejse med en gruppe venner, havde han ofte problemer, når de sad sammen om aftenen i støjende omgivelser. Det gjorde ham nedtrykt, at høreapparaterne ikke kunne hjælpe ham til at skelne de enkelte lyde, alt kogte sammen omkring ham til en grød af lyd. Hvis han tog høreapparaterne af, følte han sig ligeledes isoleret, fordi han befandt sig $\mathrm{i}$ et vakuum, hvor lyden fandtes et sted derude et par meter fra ham, uden at den gav mening.

Andre af deltagerne i undersøgelsen vælger at koncentrere sig om specifikke dele af deres livsverden, som de definerer som relevante for deres eksistens. Det vil næsten altid være væsentligt at kunne høre, hvis man vil bevare en position på arbejdsmarkedet. Men der er bestemte professioner, som i højere grad end andre kræver, at man kan høre, for at man fortsat vil blive regnet som kvalificerede interaktionspartnere. For eksempel er undervisere, advokater og dommere nogle af dem, der først erkender, at de har et høretab. Et sådant eksempel er Eigil (74), som er meget anerkendt inden for sin profession. Han bruger sine høreapparater, når han holder en forelæsning, og tilhørerne stiller spørgsmål, når han taler med sine studerende, der skriver specialer og afhandlinger, samt når han deltager i et møde, hvor deltagerne ikke er disciplinerede nok til at tale én ad gangen eller mumler (Eigils definition). Samtidig er det vigtigt for ham, at hans høreapparater ikke er synlige, fordi han frygter, at andre vil have forudfattede meninger om hans evne til at kommunikere, hvis de ved, at han er hørehæmmet. Fokus er her klart på at opretholde en magtrelation, hvor han er nødt til at lytte, være opmærksom og give passende respons på, hvad andre siger til ham. Han ved, han ikke kan opretholde sin position i det professionelle hierarki, hvis hans respons ikke er i overensstemmelse med konventionerne inden for hans profession.

Min begrundelse for overhovedet at gå ind i det høreri her, det er ... når jeg sidder i et møde med folk rundtomkring og ... hvor der ikke er sådan en ordstyrer, der kører løbet strikt, så hænder det, at jeg døjer lidt med at opsnappe tingene. Det kan være en stor fordel, fordi normalt er det noget vrøvl, folk siger, men en gang imellem er det en god idé at vide, hvad der er sket. Så mit argument for at gå ind og få det her er at følge bedre med, når der er flere, der er sammen. (Eigil, 74).

I andre situationer bruger han ikke sine høreapparater. En del af forklaringen er utvivlsomt, at høreapparatteknologien ikke kan opfylde brugernes ønsker, hvor det drejer sig om at 
adskille forskellige støjkilder, hvilket gør det svært for ham at fokusere på forskellige lyde.

I undersøgelsen er det en ofte set strategi, at humor bruges til at overvinde de forskelle, som et høretab skaber mellem mennesker. Men i Eigils tilfælde blev humor brugt til at opretholde en distance. Han fortalte, at hans kone også havde et høreproblem, og at det havde den fordel, at de ikke behøvede at tale sammen. På mit spørgsmål om, hvorvidt nogen havde foreslået, at det ville være en god idé, at han anskaffede høreapparater, svarede han: „Det ville ingen have vovet!“

Et andet eksempel på én, der skærer bestemte områder ud af sin livsverden, er Henrik (76), en pensioneret cand.mag. i fransk, som bruger sine høreapparater, når han hører foredrag eller ser sine franske yndlingsfilm i fjernsynet. Hans kone og søn havde i årevis forsøgt at overbevise ham om, at han skulle anskaffe høreapparater, men det var først, da han ikke kunne forstå en fransk film i fjernsynet, at han besluttede, at nu var det tid. Han brugte ikke høreapparaterne for at tale med sin kone. Når bare han sagde ,Ja, det er rigtigt!“, ville han ,slippe for videre tiltale“, også selv om han ikke vidste, hvad det drejede sig om. Og hun var alt for rar en person til at forsøge at presse ham - sagde han. Der er dog alt andet lige en uoverensstemmelse i de mål, som Henrik og hans pårørende har. De ønsker, at han anskaffer høreapparatet for at opretholde sociale relationer i det fælles udsnit af deres livsverden, hvorimod han prioriterer det udsnit, hvis tab ville få ham til at miste sin selvforståelse som intellektuel. Han fortalte, at han skammede sig over, at han ikke anstrengte sig mere for at gå med sine høreapparater, og at mine telefonopringninger mindede ham om hans utilstrækkelighed. Han sagde selv, at dét ikke at kunne høre fik ham til at virke ældre og mindre kvik, og at det gjorde hans kropssprog anspændt, fordi han skulle koncentrere sig og læne sig forover for at høre.

Hvis man skal betragte problemstillingen ud fra et etisk standpunkt, kan man sige, at det er arrogant af den hørehæmmede at tilsidesætte de ønsker, som hans pårørende har til kontakt. De lider et tab, fordi relationen til ham ændres. De har som alle andre mennesker krav på at blive taget alvorligt, og det kan være dybt frustrerende og trist at opleve, at ens nærmeste trækker sig fra en social kontakt. Man kan imidlertid også anlægge en anden synsvinkel. I Henriks tilfælde er det måske for sent $i$ et menneskes liv at forsøge at revolutionere det. Hvorfor skal han ikke have lov til at nøjes med at bruge sine høreapparater i de udsnit af hans livsverden, hvor han har mest glæde af dem. Imidlertid er der ved fravalget af at høre i en generel kollektiv sammenhæng en risiko for, at hans livsverden lukker sig om ham selv.

\section{Konkluderende bemærkninger}

Hørelsen er en vigtig faktor i produktionen og forhandlingen af kulturelle værdier og som sådan også i udøvelsen af social kontrol. Holdningerne til høretab har stor spændvidde 
og reflekterer generelle forskelle i livssyn. Der er i artiklen nævnt eksempler på mennesker, der ønsker at deltage i alle livets aspekter, trods deres gradvise høretab, mens andre udvælger bestemte områder, de koncentrerer sig om. De pågældendes selvforståelse har en afgørende betydning for, hvilke områder der betyder mest for dem. Jeg har fundet eksempler på, at det først er i det øjeblik, at høretabet truer den enkeltes selvforståelse, at der reageres for at opnå en bedre hørelse. Anskaffelse af høreapparat bliver således et led i den enkeltes ønske om at deltage og i samfundets disciplinering af den enkelte, idet normaliteten som hørende deltager i samfundet søges genoprettet. Høreapparater er derfor ikke kun et hjælpemiddel, idet det også for mange mennesker afspejler kulturspecifikke holdninger til normalitet, funktionsnedsættelse og kropslighed.

\section{Noter}

1. Personlig kommunikation med afspændingspædagog Eva Brix, der har et stort kendskab til problematikken omkring hørenedsættelse.

2. Materialet stammer fra den empiri, jeg har samlet i forbindelse med en endnu ikke afleveret doktorafhandling (ph.d.-afhandling) ved Institut für Kulturanthropologie und Europäische Ethnologie ved Frankfurt Universitet. Afhandlingens titel er New Hearing Aid Users. Their Expectations and Experiences. Jeg har i 2003 og 2004 fulgt 40 personer på mellem 42 og 92 år igennem den proces, det er at blive høreapparatbruger - eller ikke at blive det. Som metode har jeg valgt kvalitative interviews, i en del tilfælde også sammen med den hørehæmmedes partner, og en form for deltagerobservation, der indebærer, at jeg, i det omfang det har været muligt, har deltaget $\mathrm{i}$ undersøgelser og tilpasninger sammen med den enkelte respondent på offentlige hospitaler og hos private høreapparatudbydere. Efterfølgende har jeg haft kontakt med respondenterne for at følge udviklingen i tilpasningsprocessen. I denne artikel er der eksempler på respondenternes udtalelser, som stammer fra optagelser af interviews, min deltagelse i undersøgelser og tilpasning af høreapparater eller hukommelsesprotokoller fra opfølgende interviews. Respondenternes alder er angivet, men for at sikre deres anonymitet omtales de under pseudonym.

3. Den officielle klassifikation, „The International Classification of Functioning, Disability and Health: ICF“, defineret af WHO (WHO 2001), forbinder en fysisk funktionsnedsættelse direkte med dens sociale og kulturelle konsekvenser, som den afspejles i den måde, hvorpå samfundet opfatter og behandler funktionsnedsættelsen. En hørenedsættelse betyder begrænsning i deltagelse i det sociale liv, og de områder, der rammes, er læring, omsættelse af viden, mundtlig kommunikation, interaktion og relation med andre samt deltagelse i samfundslivet på alle niveauer (op.cit.:14). (Områderne står opført i ICF og er udvalgt af mig som dem, der især gælder for hørenedsættelse). ICF definerer ikke forskelle mellem handicap, aldersrelateret svækkelse og sygdom, men beskriver faktiske funktionsnedsættelser, som kommer til udtryk i form af indskrænkninger i handlemuligheder i mødet mellem den ramte og samfundet. For det enkelte menneske ligger forskellen mellem de tre kategorier i social konstruktion af egen og andres tilskrevne betydninger af en bestemt tilstand. Nogle hørehæmmedes angst for at blive klassificeret som handicappet afspejler samfundets angst over for fysiske defekter.

4. Personlig kommunikation med cand.theol. Jørgen Grønborg, som selv er hørehæmmet og har været præst for hørehæmmede. 


\section{Litteratur}

Boisen, Grete

1989 Psychosocial Circumstances in Connection with Hearing Impairment. Upubliceret paper præsenteret på The 10th Congress of the Nordic Audiologic Society,

Stockholm.

Christensen, Vibeke Tornhøj

2006 Uhørt? Om betydningen af nedsat hørelse i forhold til arbejdsmarkedstilknytning og arbejdsliv. København: Socialforskningsinstituttet.

Herzfeld, Michael

2001 Anthropology: Theoretical Practice in Culture and Society. Malden, MA: Blackwell Publishing.

Ihde, Don

1976 Listening and Voice: A Phenomenology of Sound. Athens, Ohio: Ohio University Press.

Murphy, Robert F.

1990 The Body Silent. New York: W.W. Norton.

Simmel, Georg

1908 Exkurs über die Soziologie der Sinne, Soziologie. Untersuchungen über die Formen der Vergesellschaftung. Berlin: Duncker \& Humblot Verlag.

Stratton, Alison

1999 Hidden Stories of Hearing Aids: Technologies and Cultures In-the-Ear. I: S. Lundin \& L. Åkesson (eds.): Amalgamations: Fusing Technology and Culture. Lund: Nordic Academic Press.

WHO

2001 International Classification of Functioning, Disability and Health: ICF. Geneva: World Health Organization. 